\title{
Does Increasing Central Government Transfer Improve Local Government Performance? A Case of Aceh Provincial Government
}

\author{
Heru Fahlevi', Muhardiansyah ${ }^{2}$, Aliamin $^{3}$ \\ ${ }^{1}$ Faculty of Economics, Syiah Kuala University, Banda Aceh, Indonesia \\ (e-mail) $\bowtie$ hfahlevi@unsyiah.ac.id \\ ${ }^{2}$ Faculty of Economics, Syiah Kuala University, Banda Aceh, Indonesia \\ $\triangle$ (e-mail) muhardiansyah14@gmail.com \\ ${ }^{3}$ Faculty of Economics, Syiah Kuala University, Banda Aceh, Indonesia \\ $\bowtie$ (e-mail) aliamin@unsyiah.ac.id
}

\begin{abstract}
The objective of this study is to evaluate the financial performance of Aceh after receiving a series of significant transfer fund under Special Autonomy Fund (SAF) since 2008. The data were collected from secondary sources i. e. 2009 to 2016 financial reports of Aceh provincial government and news from electronic media. A descriptive quantitative analysis was carried out to analyze the performance of Aceh government before and after the SAF implementation. This study demonstrates that having more money does not necessarily lead to a higher financial performance of local government. Based on the financial ratio analysis, the performance after the SAF implementation has increased slightly compared to that before SAF. Additionally, the expenditures have raised gradually particularly in regards to operational expenditures. This situation is problematic particularly after the end of SAF period as the portion of locally-generated revenue (LGR) compared the total revenue is smaller than the portion of the operational expenditures. Thus, it is imperative for the Aceh government to expand its LGR through investment and creating more revenue centers.
\end{abstract}

Keywords: local government, Special Autonomy Fund, and intergovernmental transfer

\section{Introduction}

Indonesia has started decentralization process since the 1998 reform. The decentralization is aimed to delegate more authority and autonomy to local governments. One feature of the decentralization reform is fiscal decentralization where the central government transfers more money to local governments as they are now responsible for cores governmental functions that managed centrally by the central government in the past. As the trade off, the local governments are mandated to manage several core public services to their citizen that used to be managed centrally by the central government.

The main objective of the fiscal decentralization in Indonesia is to increase financial independence as well as advancing the economy of local governments. Through fiscal decentralization, local governments (districts/ cities) can manage their revenues more flexible and thus are encouraged to improve their locally-generated revenue/LGR. Moreover, the fiscal decentralization is expected to increase the quality and the effectiveness of public spending as the decision made by the local government which know better the needs of their citizen. However, the result of fiscal decentralization in Indonesia has been far from satisfactory. After more than 15 years of fiscal decentralization, most of the local governments still heavily rely on transfers from the central government (see for example Basri, Syaparuddin, Junaidi, 2013) and the quality of public services is still fall behind other countries in ASEAN countries.

Along with Papua and Papua Barat, Aceh province has received a substantial increase of transfers from the central government. These provinces have obtained a new source of finance i.e. Special Autonomy Fund/SAF. Aceh has received the SAF since 2008 and the total amount of SAF is 163 trillion Indonesian rupiah that will be transferred within 20 years $(2008-2027)$. The purpose of this 
fund is to finance strategic program and development projects which have a strong contribution to the improvement of citizen welfare. The money should be sufficient to advance economy of the provinces and to facing a changing needs and environment of the today digital era. However, after 10 years of SAF the implementation, Aceh is still fallen behind other provinces in Indonesia.

Previous studies report divergent results of the implication of fiscal decentralization and intergovernmental funds i.e. SAF to the performance of local government. Kusuma (2016) found the positive implication of fiscal decentralization on economic growth of Indonesian local governments. In addition, Saputra and Rizki (2016) unveiled that the SAF a positive and significant influence on the human development index of districts/ cities within the Aceh province. Meanwhile, other studies, for example Basri et al. (2013) documented that the financial independence of local governments are still relatively low although they have received more transfer funds.

The objective of this study is to asses and evaluates the financial performance of Aceh government after 10 years of the SFA realization. Financial performance is one of important criteria in assessing local government performance (Darwanis and Saputra, 2014). By using the most widely used financial ratio for local government, this study unveiled the Aceh government's dependence on the intergovernmental fund from the central government and it is failed to optimize the SFA to improve LGR or to create new revenue centers. Additionally, this study also confirms the indication of the so-called fly paper effect where increasing revenue lead to higher public spending than higher citizen income (Inman, 2008; Purbarini and Masdjojo, 2015).

\section{Methods}

This study employed a descriptive quantitative approach to assess and analysis financial performance of Aceh government after the disbursement of SAF from the central government. Data is collected from financial statements of Aceh government that is collected for the period of 2008 and 2016. These data are gathered from the website of Aceh local government.

Table 1 Governmental financial ratios and its formula

\begin{tabular}{clc}
\hline No & \multicolumn{1}{c}{ Ratio } & Formula \\
\hline 1 & Independence ratio & $\frac{\text { Locally }- \text { generated revenue }}{\text { Intergovt.Transfers }+ \text { Province }+ \text { Loan }} \times 100 \%$ \\
\hline 2 & Level of decentralization & $\frac{\text { Locally - generated revenue }}{\text { Total Revenue }} \times 100 \%$ \\
\hline 3 & $\begin{array}{l}\text { Locally-generated } \\
\text { effectiveness }\end{array}$ & revenue/LGR \\
\hline 4 & Spending efficiency & $\frac{\text { Realization of LGR }}{\text { Targeted LGR }} \times 100 \%$ \\
\hline
\end{tabular}

Source: Mahmudi $(2016,164)$

There are four ratios used namely, independency ratio, level of decentralization LGR effectiveness and spending efficiency. These ratios have been widely used in evaluating the financial performance of local government in Indonesia.

The independency ratio (IR) or financial independence ratio is used to measure the ability of a local government to finance its expenditures. The higher the IR is the higher the financial autonomy of a local government. Similarly, level of decentralization is a ratio to compare revenue gained by the local government with the total revenues obtained. The LGR effectiveness reflects the capacity of local government in collected locally-generated revenue that has been budgeted. The spending efficiency indicates the efficiency of local government spending. In addition, this study also performs a trend analysis of financial statement analysis to figure out trend and pattern of revenue and expenditure of the Aceh government. By doing so, recommended strategies can be proposed to the government. 


\section{Results and Discussion}

Aceh province is located in the top of Sumatera Island and it has 23 local governments (districts and cities). After experiencing more than 30 year-political conflict and followed by Tsunami disaster in 2004, the province is now enjoying a new era of political situation and better economy. The province has been granted a special autonomy region since 2001 and received special autonomy fund (SAF) since 2008. The SAF is transferred by the central government and will be given for 20 years from 2008 to 2027. The SAF is originated from general allocation fund. In addition to that, this former conflict and tsunami affected province has received additional fund of oil and gas income sharing from the central government. The main objective of both funds is to accelerate the development and welfare of the province as it has been left behind due to conflict and 2014 tsunami disaster.

According to law on the governing of Aceh (or law No.11 2006 regarding Aceh Government), the SAF should be used for 4 core programs namely, (1) Infrastructure construction and maintenance, (2) Economy empowerment and poverty alleviation, (3) Education, (4) Health, and (5) Social and Aceh Specialty. This huge fund is managed both by provincial government ( $40 \%$ of the SAF) and district/ city government within the Aceh province $(60 \%$ of the SAF). The regulation also formulates a minimum allocated spending for infrastructure, health and education.

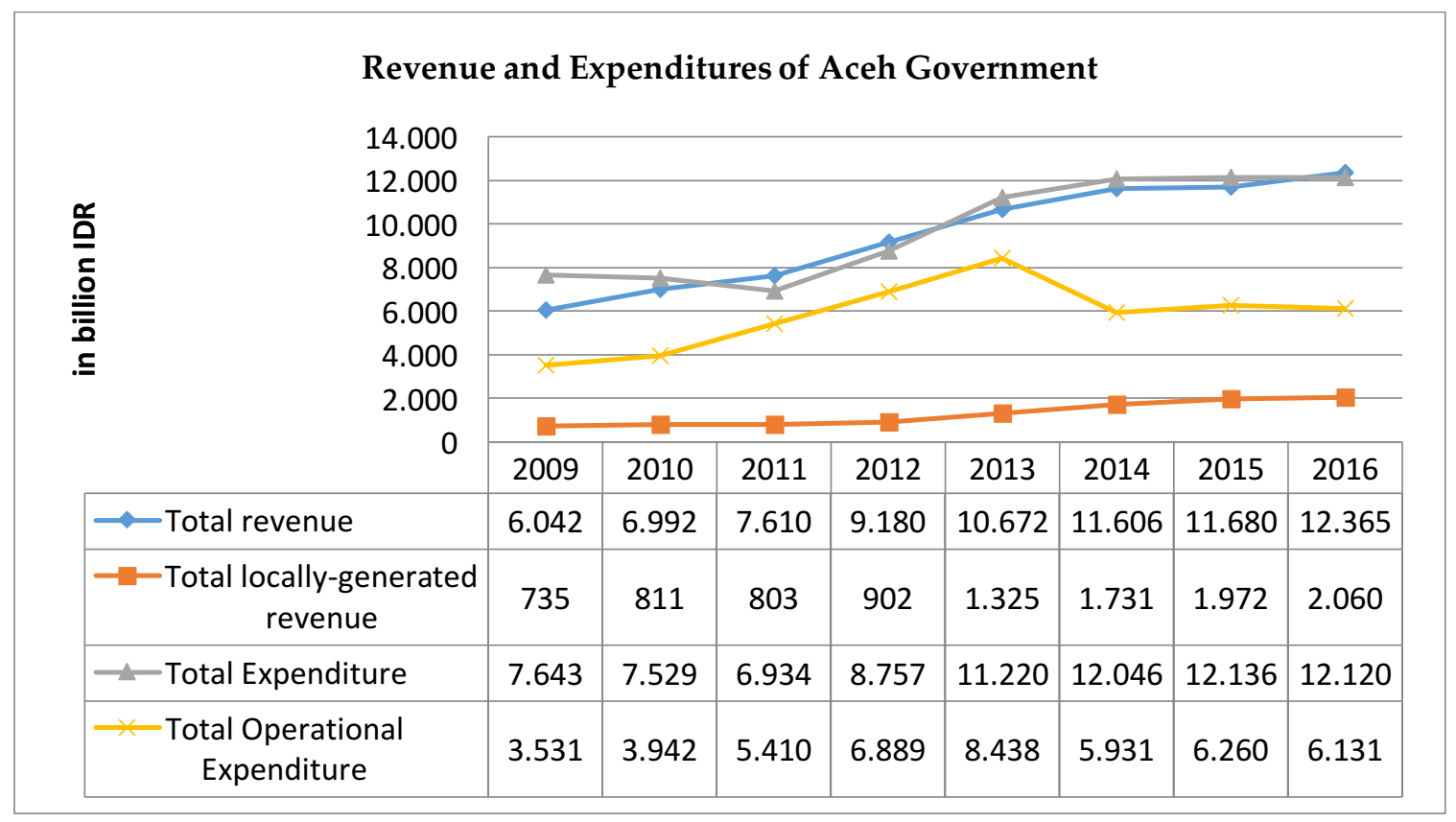

Source: Data analysis output (2017)

Figure 1. Trend of revenue and expenditure of Aceh government (2009 - 2016)

It can be clearly seen from Figure 1 that total revenue of Aceh government has doubled from around 6 trillion rupiah to more than 12 trillion rupiahs between 2009 and 2016. This substantial increase can be fully associated with the increase or the disbursement of SAF instead of other revenue. Likewise, the LGR has escalated significantly from 735 billion rupiah to more than 2 trillion rupiah. The increases of revenues are followed by the growth of Aceh expenditures. In fact, the expenditure has overlapped the revenues in many years. The total expenditures have grown almost double from 7.6 trillion rupiah to 12.1 trillion rupiah between 2009 and 2016. The increase of total expenditure can be fully linked with total operational expenditures and capital expenditures.

Based on the data analysis, the significant increase of intergovernmental transfer has stimulated high expenditures. The figure 1 shows clearly that increasing total revenue has followed by the significant increase in the total expenditure of Aceh government. In fact, the expenditures overlap the 
revenues in the beginning years of SAF implementation (2009 and 2010). The total revenue of Aceh government has doubled between 2009 and 2016, whereas the total expenditure has increased gradually over the years.

The increase in total revenues can be fully associated with SAF, rather than other sources of revenues. After 2008, the Aceh government received between 2 until 10 trillion Indonesian rupiah. Only around $12 \%$ to $16 \%$ is comes from the LGRs. Furthermore, the slight increase of the LGRs can be linked to the increase of local government tax due to the increase of economic activities in Aceh government. Although the annual increase of Aceh's LGR is $22 \%$, however, the portion of the local generate revenue is relatively very small compared to the total revenue (12-16\% of total revenue). However, this rise of the fund is followed by the increase in spending, particularly the operational expenditures. The operational expenditures comprise of salaries, social spending, grant and goods and service expenditure. The operational expenditures are accounted for more than $50 \%$ of the total expenditures of Aceh government or 6\% annual growth. Thus, it can be concluded that the LGR cannot cover the operational expenditure if SAF period is over.

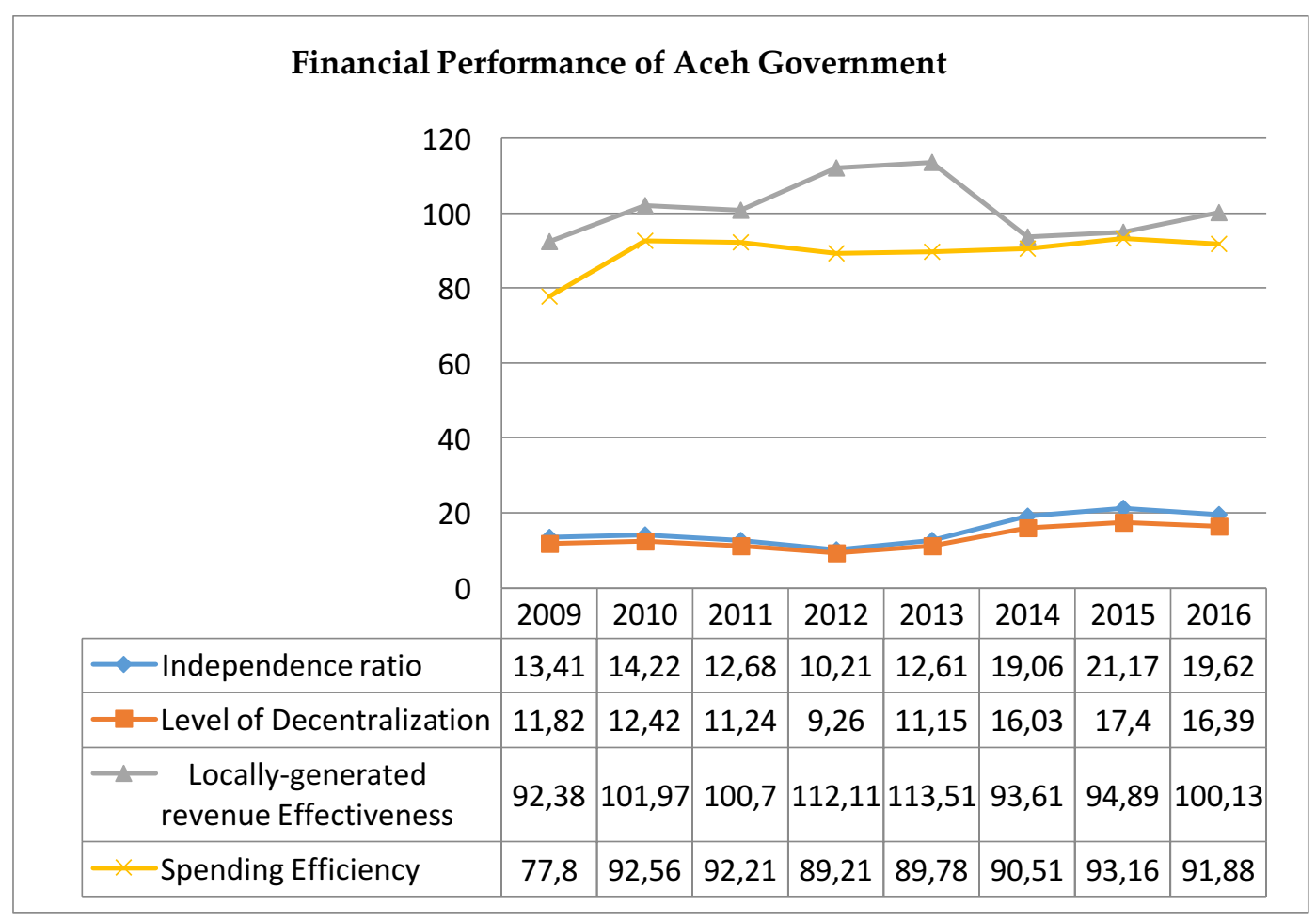

Source: Data analysis output (2017)

Figure 2. Ratio of financial independence of Aceh government (2009 - 2016)

Furthermore, the figure 2 demonstrates how financial independence ratio of Aceh government has increased since 2009. The ratio compares the LGR and the transfers from the central governments. The higher the ratio, the narrower is the difference or gap between both sources of finance. This study uncovered a relatively small dependence ratio of the Aceh government. The independence ratio is between $13.41 \%$ and $19.62 \%$. It means that the amount LGR is less than a fourth of the fund transfers. Thus, the central government plays an instructive role on the Aceh government (Halim, 2004). Moreover, the level of decentralization is also relatively low. This ratio reflects the proportion of LGR of the total revenue. The level of decentralization of Aceh government is relatively small i.e. from 9.26 to $16.39 \%$. Therefore, the classification of the decentralization of Aceh government is small (less than $20 \%)$.

The LGR effectiveness and the spending efficiency are two similar ratios which compared between budget and its realization. The Aceh government is able to generate the LGR which is higher than $100 \%$ on average in the period of study. The best explanation could be that either the Aceh 
government can optimally generate its local revenues or budgeted the LGR underestimate or without proper LGR potential assessment. There should be an evaluation of LGR budgeting process to ensure that the Aceh government collects the LGR optimally and all source of LGR is identified. Meanwhile, the spending efficiency is relatively low. This figure can be interpreted that the Aceh government cannot realize the entire budgeted program or the government can save some money from the program.

The similar situation has been uncovered also in Papua Barat which has been received SAF for a couple of years. Fanggidae, Fajir and Yuanjaya (2016) studied the performance of Papua Barat after the SAF implementation. This study demonstrates that the quality of education and other sectors is still relatively poor compared to other provinces in Indonesia. Moreover, Katit and Pinatik (2016) found the spending efficiency ratio of Asmat district, Papua province which also received the SFA, is smaller than $100 \%$.

Furthermore, the result of this study indicates that Aceh government need to improve the effectiveness of SAF. This fund should be considered as an investment to generate and to establish new sources of LGR. The government should focus on how to use the SAF to create new revenue centers. This can be done through a proper and comprehensive assessment on SAF sources and potential sources in Aceh province. Otherwise, the government will have deficit due to lack of fund after the end of SAF. More importantly, Aceh government should ensure that the proposed and financed programs or projects can improve the welfare and economy of Aceh citizen. The money should be spent wisely and optimally for projects and investments that generate measurable output and outcome.

Lastly, the Aceh government is required to improve the mechanism of program funded by the SAF. After more than 10 years of SAF implementation, the public infrastructures in Aceh province is relatively sufficient. Thus, the government needs to propose and finance programs that contribute to the improvement the quality of education, health and other important sectors. There will be challenges for the local government to propose non-infrastructure projects and therefore, the participation of important stakeholders in budgeting and planning need to be improved. Besides, there is a need to improve the capacity and skill of planners of departments (or working unit) in Aceh government because the planning of non-infrastructure projects requires in depth analysis and assessment.

\section{Conclusions}

Increasing transfer fund to local government is not always correlated with the improved financial performance of the local government. This study demonstrated that the SFA fund that has been given to Aceh government for the last 10 years has slightly increased the financial independence of the local government. However, the capability of the government to cover all expenditures is still low. In fact, the extra fund obtained has increased the operational expenditures of the Aceh government that signals the presence of flypaper effect. The flypaper effect occurs when the central government transfer to local governments tend to stimulate greater local government spending that the equivalent increase in the citizen income (Pevcin, 2011). This should be taken seriously to avoid serial deficits after the end of SAF implementation.

Furthermore, the failure of SAF to increase financial performance and non-performance is also found in Papua and Papua Barat. This indicates that the receivers of SAF face similar problem and challenges. It can indicate a systematic problem of SAF scheme, regulation and mechanism of disbursement. Thus, a comprehensive and multi-dimensional evaluation is required to improve the efficiency and effectiveness of SAF. Additionally, the central government needs to ensure and improve the quality of planners in local governments especially the receiver of SAF. There is indication that the planners in Aceh local governments have lack of capacity and experience in 
planning innovative program to improve the quality of public spending. Rather, the planners tend to spend more on infrastructures.

This study has some limitations. Firstly, the data used is only from financial reports. It is imperative to conduct interviews with key financial officers to obtain more detailed information about the performance of Aceh government. Secondly, it focuses only on financial performance and did not include non-financial performance that could be more important. Thus, further studies should take into account other sources of data and more sophisticated data analysis method including qualitative approach to understand better why improved transfer cannot improve the performance of the Aceh province.

\section{References}

Basri, H., \& Syaparuddin, Junaidi. (2013). Pemetaan kinerja pendapatan asli daerah dan kemampuan keuangan daerah kabupaten/kota di Provinsi Jambi. Jurnal Perspektif Pembiayaan dan Pembangunan Daerah, 1(2), 81-92.

Berwulo, Masinambow Wauran. (2017). Analisis pendapatan asli daerah di Kota Jayapura. Jurnal Berkala Ilmiah Efisiensi Universitas Sam Ratulangi Manado, 17(1), 22-33.

Darwanis \& Saputra, R. (2014). Pengaruh belanja modal terhadap pendapatan asli daerah dan dampaknya pada kinerja keuangan pemerintah daerah (Studi empiris pada pemerintah daerah kabupaten/kota di provinsi aceh). Jurnal Dinamika Akuntansi dan Bisnis, 1(2), 183-199.

Fanngidae, I. G., Fajri, H. \& Yuanjaya, P. (2016). Menelisik kinerja governance di daerah otonomi khusus Papua Barat. Jurnal Kajian Ilmu Administrasi Negara, 4(1), 91-106.

Halim, Abdul. \& Kusufi, Muhammad Syam. (2013). Teori, Konsep, dan Aplikasi Akuntansi Sektor Publik. Jakarta: Salemba Empat.

Inman, R. P. (2008), The flypaper effect. NBER Working Paper, No. 14579. Available at http://www.nber.org/papers/w14579.pdf

Katit \& Pinatik, (2016). Analisis kinerja belanja pada pemerintah daerah Kabupaten Asmat Provinsi Papua. Jurnal EMBA, 4(3).

Kusuma, H. (2016). Desentralisasi fiskal dan pertembuhan ekonomi di Indonesia. Jurnal Ekonomi Kuantitatif Terapan, 9(1), 1-11.

Mahmudi. (2016). Analisis Laporan Keuangan Pemerintah Daerah. Third Edition. Yogyakarta: YKPN.

Purbarini, E., \& Masdjojo, G. N. (2015). Flypaper effect on operating expenditure and capital expenditure of the city government in Indonesia. Jurnal Ekonomi Pembangunan, 16(1), 75-84.

Pevcin, P. (2011). Fly-paper effect in Slovenian municipal finances. HKJU - CCPA, 11(3), 707-728.

Saputra, M. H. \& Rizki, C. Z. (2014). Pengaruh dana otonomi khusus terhadap indeks pembangunan manusia kabupaten/kota di Provinsi Aceh. Quantitative Economics Journal, 3 (4). 